\title{
Effect of ethyl acetate extract of Melothria perpusilla on dexamethasone induced hyperglycemia in albino rats
}

\author{
Shailendra Vikram Jitendra Singh*, Ngangom Gunindro, \\ Subhalakshmi Devi Akham, Rita Devi Sanjenbam
}

Department of Pharmacology, Regional Institute of Medical Sciences, Imphal, Manipur, India

Received: 23 January 2017

Accepted: 03 February 2017

\section{*Correspondence to:}

Dr. Shailendra Vikram Jitendra

Singh,

Email:

shailendravikram121@gmail.co $\mathrm{m}$

Copyright: (C) the author(s), publisher and licensee Medip Academy. This is an openaccess article distributed under the terms of the Creative Commons Attribution NonCommercial License, which permits unrestricted noncommercial use, distribution, and reproduction in any medium, provided the original work is properly cited.

\begin{abstract}
Background: Diabetes mellitus is a group of heterogeneous disorders in which carbohydrate metabolism is reduced while that of proteins and lipids is increased. Safety and tolerability factors limit the clinical use of anti diabetic drugs. The objectives of the study were to evaluate the effect of ethyl acetate extract of Melothria perpusilla (EAEMP) on dexamethasone induced hyperglycemia in albino rats.

Methods: A set of six animals each weighing 110-150g were used for the experimental study. Successive tests were conducted on the same set of animals after a period of 10 days in between the drug administration. Blood was collected from the orbital sinus and fasting blood glucose levels were measured; $2 \%$ gum acacia suspension was administered in all the six animals followed by dexamethasone $(0.5 \mathrm{ml} / 100 \mathrm{~g})$ intraperitoneal injection. Blood glucose concentrations were estimated in the blood samples collected at $1 \mathrm{~h}$ and $2 \mathrm{~h}$ after the administration of dexamethasone administration. With the same set of animals, similar tests were repeated with the test dose of $250 \mathrm{mg} / \mathrm{kg}$ and 500 $\mathrm{mg} / \mathrm{kg}$ of the ethyl acetate extract of Melothria perpusilla and glibenclamide $[0.5 \mathrm{mg} / \mathrm{kg}$ per oral (p.o.)].

Results: Scientific data were analysed by Kruskal Wallis test. Ethyl acetate extract of Melothria perpusilla produced a significant reduction of blood glucose level when compared with control and standard.

Conclusions: Treatment with Melothria perpusilla improves hyperglycaemia probably by inhibiting gluconeogenesis.
\end{abstract}

Keywords: Diabetes mellitus, Dexamethasone, Glibenclamide, Melothria perpusilla

\section{INTRODUCTION}

Diabetes mellitus (meli $=$ honey) is a group of heterogeneous disorders in which carbohydrate metabolism is reduced while that of proteins and lipids are increased. ${ }^{1}$ The disease results into various complications which could be acute and chronic. Acute complications include marked hyperglycemia which impairs water and electrolyte balance and energy utilization, causing polyuria, polydipsia, dehydration, weight loss, and eventually if untreated, cerebral dysfunction and coma. ${ }^{2}$

According to statistical data, $2.8 \%$ of the global population suffers from this disease and it is expected to still increase to more than $5.4 \%$ by $2025 .^{3}$
Increasing prevalence, progressive nature and multi systemic outcomes highlight the need for effective pharmacotherapeutical approach to treat diabetes mellitus. Several types of glucose-lowering medicines that exert anti-diabetic effects through different mechanisms are available for the treatment of diabetes mellitus. In the past three decades, several milestones in the treatment of diabetes have been achieved but the results of treatment in patients are still far from perfect. These treatments have some disadvantages like drug resistance, side effects, and even toxicity. ${ }^{4}$

According to world ethnobotanical information reports, around 800 plants may possess antidiabetic activity. Research has been focused on scientific evaluation of traditional drugs of plant origin as well as screening of more effective and safe hypoglycemic agents and this has 
continued to be an important area of new drug development. However, lots of herbs are now being used in the management of diabetes mellitus. ${ }^{5}$

Melothria perpusilla is commonly found in the north eastern region of India and Nilgiri hills of Tamil Nadu. Melothria perpusilla is used by the local population of Manipur for treating jaundice and kidney diseases. Roots have curative action in fever and diarrhoea. Fruits possess antihelminthic property and demulcent action. ${ }^{6}$

Melothria perpusilla is a slender, hispid, perennial climber which has deeply striated, glabrous stem with cordate leaves. The fruits are globose and finely reticulate. It has oblong flattened and tuberous roots. The aerial parts of Melothria perpusilla, commonly known as "creeping cucumber" and well known as "Lamthabi" in Manipuri and Bankundri in Hindi, have been used for jaundice and kidney disorders since ages. ${ }^{7}$ Sterols and flavonol glycosides have been isolated from the chloroform extract of Melothria perpusilla and it is popular in Manipur for the traditional treatment of jaundice. ${ }^{8,9}$ Unfortunately, significant scientific data are not available in literature to substantiate the various traditional medical uses of the plant.

\section{METHODS}

\section{Study approval}

The whole experimental protocol was approved and constituted in accordance with the rules and guidelines of the Institutional Animal Ethics Committee for the purpose of control and supervision on experiments in animals, India.

\section{Place of study}

The experimental study was conducted in the Department of Pharmacology, R.I.M.S., Imphal, Manipur.

\section{Animals}

Six healthy albino rats of either sex (12-14 weeks) weighing between 110-150g were obtained from the animal house, R.I.M.S., Imphal. Albino rats housed in polypropylene animals cages and acclimatized in the Departmental animal room in the standard conditions of temperature, relative humidity $(55 \pm 5 \%)$, and light $(12 \mathrm{~h}$ light/dark cycles) were used. Rats were fed with standard pellet diet and water with free access to water.

\section{Collection of plants}

Melothria perpusilla plants were collected from the campus of Regional Institute of Medical Sciences, Imphal West District, Manipur during the months of JuneAugust, 2015.

\section{Identification of plant}

Prof. H. Nandiram Sharma, (retired) Professor of Botany, Manipur University identified and authenticated the plant.

\section{Plant extract preparation}

Aerial portions were completely shade dried in air and powdered using mixer grinder and later on subjected to defatting process using petroleum ether (B.P. $\left.40^{\circ}-60^{\circ}\right) .^{10}$ The plant material was emptied and thoroughly washed using 95\% ethyl alcohol and solvent was completely evaporated by spreading the plant materials which were later repacked with the dried plant material; thus, the test compound was obtained by using ethyl acetate solvent. $^{11,12}$ Soxhlet apparatus was used for the preparation of plant extract. ${ }^{13}$ The yield at the end of extraction was calculated to be $0.36 \%$.

\section{Preliminary photochemical study}

Lead acetate solution on addition to a small quantity of the plant extract, gave a yellow coloured precipitate. Sodium hydroxide solution on addition to a small quantity of the extract produced a yellow coloured precipitate which turned colourless when dilute acid was added. Both of these tests reveal the presence of flavonoids.

\section{Acute toxicity study}

Melothria perpusilla was used since thousands of years by the local population of Manipur for treatment of various diseases. The limit test of the test compound was conducted. Ethyl acetate extract of Melothria perpusilla (EAEMP) was administered in experimental albino rats at one dose level of $2000 \mathrm{mg} / \mathrm{kg}$ per orally. At the dose of $2000 \mathrm{mg} / \mathrm{kg}$ per orally, there was no mortality and thus two working doses of $250 \mathrm{mg} / \mathrm{kg}$ and $500 \mathrm{mg} / \mathrm{kg}$ were chosen for further experimental study. ${ }^{14}$

\section{Experimental study}

Hyperglycaemia was induced by the method of $\mathrm{Md}$. Salam et al. ${ }^{15}$ The same set of six animals were used throughout for the experimental study. Blood was collected from the orbital sinus by capillary tube following engorgement of retro orbital sinuses. After collecting and measuring the fasting blood glucose levels, $2 \%$ gum acacia suspension $(10 \mathrm{ml} / \mathrm{kg}$ per oral) was administered in all the six albino rats followed by dexamethasone $(0.5 \mathrm{ml} / 100 \mathrm{~g})$ intraperitoneal injection. Blood glucose concentrations were estimated in the blood samples collected at $1 \mathrm{~h}$ and $2 \mathrm{~h}$ after the administration of the dexamethasone administration. Using the same set of animals, similar tests were repeated with the test dose of $250 \mathrm{mg} / \mathrm{kg}$ and $500 \mathrm{mg} / \mathrm{kg}$ of the ethyl acetate extract of Melothria perpusilla and glibenclamide (0.5 mg/kg p.o.). Duration of 10 days was maintained in between the successive tests for washing out of the drug from animals 
to prevent the interference of action of one drug with the other.

\section{Statistical analysis}

Blood glucose levels were expressed as Mean \pm Standard deviation. The non parametric data were analysed by Kruskal Wallis test. IBM SPSS software version 23.0 was used for analysis of the data; $p<0.05$ was considered statistically significant.

\section{RESULTS}

The effect of ethyl acetate extract of Melothria perpusilla on dexamethasone induced hyperglycaemia were studied in the albino rats.

Blood glucose level in the overnight fasted albino rats of (a) control, (b) test 1 (250 mg/kg), (c) test $2(500 \mathrm{mg} / \mathrm{kg})$, (d) standard drug (glibenclamide $0.5 \mathrm{mg} / \mathrm{kg}$ ) groups were $71.00 \pm 0.58, \quad 70.83 \pm 1.40, \quad 69.50 \pm 0.89, \quad 68.17 \pm 3.06$ respectively. Blood glucose level after $1 \mathrm{~h}$ treatment of control (2\%gum acacia followed by dexamethasone 0.5 $\mathrm{ml} / 100 \mathrm{~g}$ i.p.) and then after test $1(250 \mathrm{mg} / \mathrm{kg})$, test 2 $(500 \mathrm{mg} / \mathrm{kg}$ ) and standard (glibenclamide $0.5 \mathrm{mg} / \mathrm{kg}$ ) which were administered after the drug wash out period of 10 days on each occasion were 193.67 \pm 3.58 , $159.50 \pm 3.84,120.00 \pm 3.15,112.33 \pm 2.39$ respectively.

The average increase with the fasting blood glucose level values was 122.67 in the control group, and 88.67, 50.50, 44.16 in the test 1 , test 2 and standard group respectively. The increase in the blood glucose level after $2 \mathrm{~h}$ of treatment conducted in the same way was 84.33, 63.00, $35.83,31.50$ in the test 1 , test 2 and standard group respectively. Test 1 , test 2 and standard showed highly significant reduction in blood glucose level $(p<0.01)$ when compared with control. Test 2 showed a highly significant reduction in blood glucose level $(\mathrm{p}<0.01)$ when compared with test 1 (Table 1).

Table 1: Effect of ethyl acetate extract of Melothria perpusilla on dexamethasone induced hyperglycaemia.

\begin{tabular}{|c|c|c|c|}
\hline & \multicolumn{3}{|c|}{ Blood glucose [mg\% (Mean \pm SD)] } \\
\hline & Fasting & $1 \mathrm{~h}$ & $2 \mathbf{h}$ \\
\hline Control & $71.00 \pm 0.58$ & $193.67 \pm 3.58^{\#}$ & $155.33 \pm 2.75^{\#}$ \\
\hline Test 1 & $70.83 \pm 1.40$ & $159.50 \pm 3.84^{* \#}$ & $133.83 \pm 3.56^{* \#}$ \\
\hline Test 2 & $69.50 \pm 0.89$ & $120.00 \pm 3.15^{*}$ & $105.33 \pm 3.84^{*}$ \\
\hline Standard & $68.17 \pm 3.06$ & $112.33 \pm 2.39^{*}$ & $99.67 \pm 3.07^{*}$ \\
\hline $\begin{array}{l}\text { Values are } \\
* \mathrm{p}<0.01 \mathrm{w} \\
\# \mathrm{p}<0.001 \\
. \mathrm{p}<0.01 \mathrm{wl}\end{array}$ & $\begin{array}{l}\text { Iean } \pm \text { SD } \\
\text { en compared } \\
\text { hen compare } \\
\text { en compared }\end{array}$ & $\begin{array}{l}\text { h control } \\
\text { th standard } \\
\text { Test } 1\end{array}$ & \\
\hline
\end{tabular}

\section{DISCUSSION}

Glucocorticoids exert prominent anti-insulin effects through various mechanisms such as by decreasing the peripheral utilisation of glucose by reducing its cellular uptake, enhancing the expression of the hepatic enzymes involved in gluconeogenesis and stimulating glucose synthesis from amino acids and inhibition of protein synthesis in muscle, connective tissue and skin for gluconeogenesis by mobilising amino acids. ${ }^{16}$ Dexamethasone produces effects after a characteristic period of $0.5 \mathrm{~h}$ to several hours - the time required for the synthesis of new proteins. ${ }^{17}$ Dose of $0.5 \mathrm{ml} / 100 \mathrm{~g}$ i.p. dexamethasone was used to induce hyperglycaemia. A single dose of glucocorticoids, even a large one, is free from any harmful effects. ${ }^{18}$ Glibenclamide at the dose of $0.5 \mathrm{mg} / \mathrm{kg}$ p.o. (extrapolated from human dose) showed highly significant decrease $(\mathrm{p}<0.01)$ in $1 \mathrm{~h}$ and $2 \mathrm{~h}$ blood glucose changes of dexamethasone induced hyperglycaemia when compared with that of control. The highly significant reduction in blood glucose produced by test $1(250 \mathrm{mg} / \mathrm{kg})$ and test $2(500 \mathrm{mg} / \mathrm{kg})$ at $2 \mathrm{~h}$ compared with that of control indicated that dexamethasone is probably having inhibitory effect on gluconeogenesis.

\section{CONCLUSION}

In the above study, the test drug at the dose of $250 \mathrm{mg} / \mathrm{kg}$ and $500 \mathrm{mg} / \mathrm{kg}$ showed significant reduction in blood glucose level probably by inhibiting gluconeogenesis.

Funding: No funding sources

Conflict of interest: None declared

Ethical approval: The study was approved by the Institutional Animal Ethics Committee (IAEC), Regional Institute of Medical Sciences (R.I.M.S.), Imphal, Manipur. Registration No. 1596/GO/a/12/CPCSEA

\section{REFERENCES}

1. Sharma HL, Sharma KK. Principles of Pharmacology. 2nd ed. Delhi: Paras Medical Publishers; 2011:630.

2. Carla J, Greenbaum, Leonard C, Harrison. Diabetes: translating research into practice. Informa health care; 2008:1-2.

3. Mukesh R, Namita P. Medicinal plants with antidiabetic potential-A review. American-Eurasian J Agric Environ Sci. 2013;13(1):81-94.

4. Dey L, Attele AS, Yuan CS. Alternative therapies for type 2 diabetes. Altern Med Rev. 2002;7:45-58.

5. Yaheya M, Ismail M. World Appl Sci J. 2009;7(10):1231-4.

6. Kiritikan KR, Basu BD. Melothria perpusilla Cogn. In: Blatter E, Caius JF, Mlaskar KS, editors. Indian Medicinal Plant. 2nd ed. Dehradun: International Book Distributors; 1987:161-2.

7. Leisangthem S, Sharma LD. Study of some important medicinal plants found in Imphal-East District, Manipur, India. Int J Scien Res Pub. 2014;4(9):3.

8. Sinha SC. Medicinal plants of Manipur, Imphal (Manipur): Manipur Association for Science and Society (MASS); 1996. 
9. Langoljam RD, Kongbrailatpam BD, Loitongjam WS. Sterols and flavonol glycosides from Melothria perpusilla Cogn. Indian J Chem. 2005;44(B):1291-4.

10. Beckett AH, Stenlake JB. Solvent extraction methods practical pharmaceutical chemistry. $3^{\text {rd }}$ ed. London: The Anthlone Press; 1975.

11. Chattopadhyay RR, Sarkar SK, Ganguly S, Banerjee $\mathrm{RN}$, Basu TK. Indian J Physiol Pharmacol. 1991;35(3):45-51.

12. Brahmachari HD, Augusti KT. Isolation of orally effective hypoglycaemic compounds from Ficus bengalensis Linn. Indian $\mathrm{J}$ PhysiolPharmacol. 1964;8:60-4.

13. Knevel AM, Digangi FE. Jenkin's Quantitative Pharmaceutical Chemistry. $7^{\text {th }}$ ed. New York: Mc Graw Hill Book Co; 1977.

14. OECD Test Guideline 423: Acute oral toxicityAcute toxic class method. Available from: http://iccvam.niehs.nih.gov/SuppDocs/FedDocs/OEC D/OECD_GL423.pdf. Accessed on Dec 21, 2016.

15. Md. Shalam, Harish MS, Farhana SA. Prevention of dexamethasone and fructose- induced insulin resistance in rats by $\mathrm{SH}-01 \mathrm{D}$, a herbal preparation. Indian J Pharmacol. 2006;38:419-22.

16. Sharma HL, Sharma KK. Principles of Pharmacology. $2^{\text {nd }}$ ed. Delhi: Paras Medical Publishers; 2011:565.

17. Bourne HR, Zastro MV. Drug receptors and Pharmacodynamics, In: Katzung BG, editor. Basic and Clinical pharmacology. $8^{\text {th }}$ ed. New York: McGraw Hill; 2001:9-34.

18. Schimmer BP, Parker KL. Adrenocorticotropic hormone; Adrenocorticol steroids and their synthetic analogs; Inhibitors of the synthesis and actions of Adrenocortical hormones. In: Hardman JG, Limbard LE, Gilman AG, editors. Goodman and Gillman's the Pharmacological Basis of Therapeutics. $10^{\text {th }}$ ed. New York: Mc Graw Hill; 2001:1649-1677.

Cite this article as: Singh SVJ, Gunindro N, Akham SD, Sanjenbam RD. Effect of ethyl acetate extract of Melothria perpusilla on dexamethasone induced hyperglycemia in albino rats. Int $\mathbf{J}$ Basic Clin Pharmacol 2017;6:807-10. 